\title{
Tropical kudzu as a protein source in sheep diets
}

\section{Puerária como fonte proteica em dietas de ovinos}

\author{
Camila Carvalho da $\mathrm{Paz}^{1 *}$; Aníbal Coutinho do Rêgo²; Cristian Faturi²; \\ Luiz Fernando de Souza Rodrigues²; José Adérito Rodrigues Filho; \\ Paulo Henrique de Souza ${ }^{1}$; Dayana Mesquita Conceição ${ }^{4}$
}

\begin{abstract}
Protein nutrition plays a key role in ruminant performance and represents the largest proportion of costs in animal feed. The present study evaluated whether the roughage portion of Santa Inês sheep diets could be supplemented with different ratios of tropical kudzu as a protein source and assessed the best inclusion level of tropical kudzu based on digestibility, intake, nitrogen balance and feeding behavior. Twenty rams were evaluated during the 20-day experimental period, and they were fed formulated diets with a roughage portion (60\%) consisting of Elephant grass and tropical kudzu, the latter supplemented at different concentrations $(0,25,50$ and $75 \%$ on a dry matter basis). Forty percent of the concentrate portion consisted primarily of ground corn and soybean meal adjusted to obtain an isoproteic diet. Chemical and bromatological analyses, as well as, analyses to assess intake, digestibility, nitrogen balance and feeding behavior, were conducted. No statistically significant differences were found $(\mathrm{P}>0.05)$ for the intake and digestibility of dry matter $(\mathrm{DM})$, crude protein $(\mathrm{CP})$, ether extract (EE), neutral detergent fiber (NDF), hemicellulose (HEMI), non-fiber carbohydrates (NFC) and total digestible nutrients (TDN) or for the feeding behavior (feeding, rumination and idle times in h/day) and nitrogen balance between the diets studied. Thus, tropical kudzu can be considered a feed alternative to supplementation with prime protein foods (in this case, soybean meal) in sheep diets.
\end{abstract}

Key words: Digestibility. Legume. Pennisetum purpureum. Pueraria phaseoloides. Protein supplementation.

\section{Resumo}

Objetivou-se com o presente estudo avaliar a inclusão na porção volumosa de diferentes porções de puerária como fonte proteica em dietas de ovinos da Raça Santa Inês, determinando a melhor concentração de inclusão de puerária com base na digestibilidade, consumo, balanço de nitrogênio e comportamento ingestivo. Durante os 20 dias do período experimental, foram utilizados 20 ovinos, que receberam dietas formuladas, cuja porção volumosa $(60 \%)$ foi constituída por capim-Elefante e puerária, incluída em diferentes concentrações $(0 ; 25 ; 50$ e $75 \%$ com base na matéria seca). Os $40 \%$ da porção concentrada foram constituidos a base de milho moído e farelo de soja ajustados para obtenção de dietas isoprotéicas. Foram realizadas análises químico-bromatológicas, bem como análises para determinação

\footnotetext{
${ }^{1}$ Discentes do Curso de Doutorado do Programa de Pós-Graduação em Saúde Produção Animal na Amazônia, Instituto da Saúde e Produção Animal, Universidade Federal Rural da Amazônia, UFRA, Belém, PA, Brasil. Bolsistas CAPES. E-mail: cpaz.camila@ gmail.com; phszootecnista@msn.com

2 Profs. Drs., Instituto da Saúde e Produção Animal, UFRA, Belém, PA, Brasil. E-mail: anibalcr@gmail.com; cristian.faturi@ufra. edu.br; luiz.rodrigues@ufra.edu.br

3 M.e, Pesquisador, Embrapa Amazônia Oriental, Belém, PA, Brasil. E-mail: jose.rodrigues-filho@embrapa.br

4 Zootecnista, Discente do Curso de Mestrado do Programa de Pós-Graduação em Saúde Produção Animal na Amazônia, Instituto da Saúde e Produção Animal, UFRA, Belém, PA, Brasil. Bolsista CAPES. E-mail: dayana.mesquitac@gmail.com

* Author for correspondence
} 
de consumo, digestibilidade, balanço de nitrogênio e análise do comportamento ingestivo. Não foram observadas diferenças $(p>0,05)$ no consumo e digestibilidade de MS; PB, EE, FDN, HEMI, CNF e nos valores de NDT, bem como no comportamento ingestivo (tempos de alimentação, ruminação e ócio em $\mathrm{h} /$ dia) e balanço de nitrogênio entre as dietas estudadas. A puerária é uma alternativa de alimento à inclusão de alimentos protéicos nobres (no caso, farelo de soja) em dietas de ovinos.

Palavras-chave: Digestibilidade. Leguminosa. Pennisetum purpureum. Pueraria phaseoloides. Suplementação proteica.

\section{Introduction}

Brazil is a leader in the production of commodities destined for the food market and ranks among the largest producers in the global livestock sector. Among the various types of animals bred in the country, the production of sheep has shown a steady growth trend in the past decade (IBGE, 2013).

The intensification of pastoral production systems is considered an alternative for sustainable exploitation because it minimizes the pressure to establish new areas for agricultural production. However, such models are guided by the efficient use of natural resources, including the restoration of anthropized and degraded areas, based on contributions from research and input-saving technologies (BARCELLOS et al., 2008).

The knowledge and the use of techniques involving the nutrition and reproduction, as well as health and breeding, of sheep are among the various methods of improving productivity rates, and the use of animal feed to promote optimal production yield relative to the animal's nutritional requirements is a method of promoting advances in the supply chain. Investments in animal nutrition represent the largest portion of the costs in a production system; therefore, the use of alternative foods instead of prime foods may be a method of minimizing feeding costs (VASTA et al., 2008).

Protein nutrition plays a key role in ruminant performance because of the low availability of proteins in pastures; a low protein portion in the total diet is one of the main contributors to low animal production performance (ALVES et al., 2009). However, protein foods represent the largest proportion of animal feed costs worldwide (WILKINS; JONES, 2000), and the vast majority of Brazilian nutritionists still suggest expensive sources, including soy bean meal, when formulating diets (MILLEN et al., 2009). Thus, the use of alternative protein foods, including legumes, should be examined for their contribution towards reducing feeding costs in production systems.

The advantages of including legumes in sheep nutrition related to animal production have been described in previous studies (VAN HIEP et al., 2008; TERRILL et al., 2003; CORLEY et al., 1997). Such advantages include enhanced animal production as a result of the increased protein concentrations, digestibility and intake of available forage, improved distribution of pasture production throughout the year, improved available proteinenergy balance (SILVA et al., 2014), increased concentration of minerals (particularly calcium) and increased soil fertility upon nitrogen addition to the soil-plant-animal system (MIRANDA et al., 2003; ALMEIDA et al., 2015).

Legumes are forage plants that play a significant role in animal production; in addition, they represent a high-protein source in animal supplementation and have the ability to perform biological fixation of atmospheric nitrogen to the soil. These characteristics result in a quantitative and qualitative increase in the production of food provided to animals as well as an increase in the food's nutritional value, which favorably affects animal performance (ROTZ, 1995).

Tropical kudzu (Pueraria phaseoloides) is considered one of the most promising legumes in the Amazon region. Because pastures are generally 
cultivated with and formed by grasses, tropical kudzu emerges as a rather valuable option for improving animal production activity because of its high nutritional value, high palatability, increased drought resistance and ability to incorporate significant amounts of nitrogen into the soil (CORLEY et al., 1997). In addition, it is used in protein supplementation of farm animals through its cultivation in forage reserve areas.

This study was conducted to examine the possibility of supplementing sheep diets with legumes based on the nutritional aspects of legumes and to evaluate whether prime foods can be replaced in animal diets by alternatives so that more sustainable animal production activities may be developed. Thus, the present study aimed to evaluate the dietary supplementation of Santa Inês sheep with different concentrations of tropical kudzu as a protein source through intake, digestibility, nitrogen balance and feeding behavior experiments.

\section{Materials and Methods}

The present study was submitted to the Ethics Committee on Animal Use of the Federal Rural University of the Amazon (Comitê de Ética no Uso de Animais da Universidade Federal Rural da Amazônia - CEUA/UFRA) and was approved under protocol number 007/2012 (CEUA) 23084.013637/2012-21 (UFRA).

The experiment was carried out at the Center for Research on Goats and Sheep of Pará State (Centro de Pesquisas em Caprinos e Ovinos do Estado do Pará - CPCOP/UFRA) and Metabolic Research Unit on Small Ruminants (Unidade de Estudos Metabólicos de Pequenos Ruminantes -UEMPR), which is located at the University Campus of UFRA in Belém, a mesoregion of Pará State (PA), geographically located at $1^{\circ} 27^{\prime} 15^{\prime}$ 'S , 48 $26^{\circ} 50^{\prime \prime} \mathrm{W}$ at an altitude of 14 meters above sea level.

The regional climate is characterized as Af (tropical humid) according to the Köppen-Geiger climate classification, with an average annual temperature of $25.9^{\circ} \mathrm{C}$ and monthly mean maximal and minimal temperatures of 31.4 and $21.9{ }^{\circ} \mathrm{C}$, respectively. Moreover, the climate is characterized by high rainfall levels, with an average annual rainfall of approximately $3001 \mathrm{~mm}$ and the highest concentration of rainfall from December to May. The area shows an annual average relative air humidity of $84.0 \%$ and an annual average solar radiation of $2338.3 \mathrm{~h}$.

Two areas were focused in this study: one with tropical kudzu and another with Elephant grass. Liming was conducted in both areas according to recommendations based on soil analyses, which classified the soil as sandy loam in the $0-20 \mathrm{~cm}$ layer with ratios of $75.13 \%$ sand, $11.46 \%$ silt and $13.41 \%$ clay. The soil chemical characteristics were as follows: $\mathrm{pH}$ (in water) $=5.3 ; \mathrm{P}=2.27 \mathrm{mg} / \mathrm{dm}^{3}$; organic matter $=22.24 \mathrm{~g} / \mathrm{kg} ; \mathrm{Ca}^{+2}=1.71 \mathrm{cmol} . /$ $\mathrm{dm}^{3}$ soil; $\mathrm{Mg}^{+2}=0.19$ cmolc. $/ \mathrm{dm}^{3}$ soil; $\mathrm{K}^{+}=0.05$ cmolc. $/ \mathrm{dm}^{3}$ soil; $\mathrm{Al}^{+3}=0.33$ cmolc. $/ \mathrm{dm}^{3}$ soil; and $\mathrm{H}^{+}=6.94$ cmolc. $/ \mathrm{dm}^{3}$ soil. Moreover, fertilization with minerals (macro and micronutrients) was also conducted. The fertilization in the Elephant grass area was conducted at planting by applying $120 \mathrm{~kg} /$ ha $\mathrm{P}_{2} \mathrm{O}_{5}(00-20-00)$ and $60 \mathrm{~kg} / \mathrm{ha} \mathrm{K}_{2} \mathrm{O}$ in the form of potassium chloride. Elephant grass was planted using seed lings in furrows with a 1-m spacing and a $15-\mathrm{cm}$ depth. The tropical kudzu area received no nitrogen fertilization, and planting was conducted in rows using seeds, whose dormancy was broken using the method of boiling water at $75^{\circ} \mathrm{C}$ for 15 minutes (VALENTIM; CARNEIRO, 1998).

Twenty Santa Inês rams were used in the metabolic assay, and they exhibited a mean mass of $32.5 \pm 3.98 \mathrm{~kg}$ and were approximately three months of age. The rams were kept in individual metabolic wooden cages with an area of $0.79 \mathrm{~m}^{2}$ $(1.31 \times 0.60 \mathrm{~m})$. The cages were maintained in a protected (barn) and well-ventilated environment. The experiment lasted 20 days, with 14 days for the adaptation period, 5 days for data collection and 1 day (last) for the observation of feeding 
behavior. The animals were fed formulated diets at a 60:40 roughage:concentrate ratio (Table 1), with a roughage portion consisting of Elephant grass and tropical kudzu, the latter supplemented at different concentrations $(0,25,50$ and $75 \%$ on a dry matter basis). Forty percent of the concentrate portion consisted primarily of ground corn and soybean meal that were adjusted to obtain an isoproteic diet. A water and mineral mixture was provided ad libitum. Table 2 shows the ratios of each ingredient in the different diets and their bromatological compositions.

Table 1. Chemical-bromatological composition and proportion of ingredients used in the elaboration of the experimental diets.

\begin{tabular}{lcccc}
\hline \multicolumn{1}{c}{ Composition } & Tropical kudzu & Elephant grass & Soybean meal & Corn \\
\hline DM (\%) & 22.61 & 19.5 & 86.92 & 86.72 \\
OM (\%) & 93.33 & 95.31 & 13.08 & 13.28 \\
MM (\%DM) & 6.34 & 4.69 & 7.16 & 1.24 \\
CP (\%DM) & 18.75 & 6.17 & 49.1 & 9.3 \\
EE (\%DM) & 2.01 & 3.22 & 0.33 & 0.49 \\
NDF (\%DM) & 64.02 & 69.86 & 16.37 & 8.98 \\
Hemicellulose (\%DM) & 18.96 & 29.58 & 3.66 & 2.99 \\
Lignin (\%DM) & 9.22 & 5.04 & 3.75 & 0.31 \\
TC (\%DM) & 72.90 & 85.92 & 43.41 & 88.97 \\
NCF (\%DM) & 8.87 & 16.07 & 27.04 & 79.99 \\
NDIN (\%total N) & 13.4 & 34.3 & 5.7 & 9.8 \\
ADIN (\%total N) & 6.5 & 2.9 & 2.1 & 3.1 \\
\hline
\end{tabular}

$\mathrm{DM}=$ dry matter; $\mathrm{OM}=$ organic matter; $\mathrm{MM}=$ mineral matter $($ ash) $\mathrm{CP}=$ crude protein; $\mathrm{EE}=$ ether extract; $\mathrm{NDF}=$ neutral detergent fiber; HEMI = hemicellulose; TC $=$ total carbohydrates; NFC $=$ non-fiber carbohydrates; NDIN $=$ neutral detergent insoluble nitrogen; ADIN = acid detergent insoluble nitrogen.

Ivermectin was administered subcutaneously at a dose of $0.5 \mathrm{~mL} / 25 \mathrm{~kg}$ body weight at the beginning of the experimental period as a prophylactic measure to control verminosis. After the animals were weighed, they were randomly selected and allocated to the respective treatments.

Elephant grass and tropical kudzu were minced, weighed and mixed manually with the concentrate daily. To ensure the voluntary intake by the animals, the diets were supplied twice daily at 8 am and 4 $\mathrm{pm}$ in amounts that allowed for approximately $10 \%$ of the total to remain as leftovers. The feed and leftovers collected during the 24-hour period were weighed and recorded during the collection period. The dietary intake was calculated as the difference in weight between the feed supplied and leftovers.

Chemical and bromatological analyses were conducted to quantify the nutritional value of each diet. Samples of the feed, leftovers and feces were collected and weighed daily during the collection period. Subsamples corresponding to $10 \%$ of the total weighed for each sample or a minimum value of $300 \mathrm{~g}$ were collected and then frozen. 
Table 2. Proportion of ingredients and chemical composition of experimental diets.

\begin{tabular}{lcccc}
\hline \multirow{2}{*}{ Feedstuffs } & \multicolumn{4}{c}{ Concentrations of tropical kudzu in the roughage } \\
\cline { 2 - 5 } & $0 \%$ & $25 \%$ & $50 \%$ & $75 \%$ \\
\hline Elephant grass & 61.3 & 45.9 & 30.6 & 15.3 \\
Tropical kudzu & 0 & 15,3 & 30.6 & 45.9 \\
Corn & 24.92 & 28.4 & 31.89 & 35.35 \\
Soybean meal & 13.39 & 10.01 & 6.52 & 3.07 \\
Calcitic Calcareous & 0.39 & 0.39 & 0.39 & 0.39 \\
\hline \multicolumn{1}{c}{ TOTAL } & 100 & 100 & 100 & 100 \\
\hline \multicolumn{1}{c}{ Composition } & $0 \%$ & $25 \%$ & $50 \%$ & $75 \%$ \\
\hline DM (\%) & 45.20 & 45.74 & 46.21 & 46.69 \\
OM (\%) & 63.49 & 63.11 & 62.81 & 62.52 \\
MM (\%DM) & 4.14 & 4.19 & 4.24 & 4.29 \\
CP (\%DM) & 12.67 & 13.26 & 13.79 & 14.35 \\
EE (\%DM) & 2.14 & 1.96 & 1.78 & 1.60 \\
NDF (\%DM) & 47.25 & 46.05 & 44.90 & 43.75 \\
Hemicellulose (\%DM) & 19.37 & 17.69 & 16.05 & 14.40 \\
Lignin (\%DM) & 3.67 & 4.19 & 4.71 & 5.23 \\
TC (\%DM) & 80.65 & 80.20 & 79.80 & 79.39 \\
NCF (\%DM) & 33.41 & 34.16 & 34.90 & 35.64 \\
\hline
\end{tabular}

$\mathrm{DM}=$ dry matter; $\mathrm{OM}=$ organic matter; $\mathrm{MM}=$ mineral matter (ash); $\mathrm{CP}=$ crude protein; $\mathrm{EE}=$ ether extract; $\mathrm{NDF}=$ neutral detergent fiber; HEMI $=$ hemicellulose; TC $=$ total carbohydrates; $\mathrm{NFC}=$ non-fiber carbohydrates.

The samples of the feed, leftovers and feces were thawed at room temperature and subsequently weighed and placed in a forced-air oven at $55{ }^{\circ} \mathrm{C}$ for 72 hours. The pre-dried samples were then ground in a Wiley mill using a 1-mm mesh sieve and stored in lidded polyethylene containers for subsequent assessment of DM (dry matter) and CP (crude protein), according to the method proposed by the Association of Official Analytical Chemists - AOAC (1990). The levels of MM (mineral matter or ash) were also assessed by burning the organic matter (OM) in a muffle furnace at $600^{\circ} \mathrm{C}$ for 4 hours, and the EE (ether extract) levels were assessed using a Goldfish fat extractor for $4 \mathrm{~h}$. The feed neutral detergent fiber (NDF) and hemicellulose (HEM) levels were assessed using a device from ANKOM Technology (Macedonia, NY,
United States) according to the method reported by Van Soest e Wine (1967). The levels of lignin (LIG) were assessed using the acid detergent fiber (ADF) residue according to the method by Van Soest e Wine (1967).

The levels of total carbohydrates (TCHO) were calculated as follows: $100-(\% \mathrm{CP}+\% \mathrm{EE}+\% \mathrm{MM})$; the levels of non-fiber carbohydrates (NFC) were calculated as follows: TCHO - NDFcp (SNIFFEN et al., 1992). The equation proposed by the National Research Council (NRC, 2007) was used to assess the total digestible nutrients (TDN): TDN $=\mathrm{CPd}+$ EEdx2.25 + NDFd + NFCd, where CPd, EEd and NFCd represent the digestible (d) portion of each nutrient.

The apparent digestibility (DIG) of nutrients was calculated using the following equation:

$$
\mathrm{DIG}=\frac{[(\mathrm{ING} x \% \mathrm{ING})-(\mathrm{LEFT} x \% \mathrm{LEFT})-(\mathrm{FEC} x \% \mathrm{FEC}) \times 100}{(\mathrm{ING} x \% \mathrm{ING})-(\mathrm{LEFT} x \% \mathrm{LEFT})}
$$


where ING $=$ the amount of feed ingested; $\% \mathrm{ING}$ $=$ the nutrient levels in the feed supplied; LEFT $=$ the amount of leftovers collected; \%LEFT $=$ the nutrient levels in the leftovers; FEC $=$ the amount of feces collected; and $\% \mathrm{FEC}=$ the nutrient levels in the feces.

The urine produced by each individual during the collection period was weighed, and the volume of urine produced was also measured (SCHNEIDER; FLATT, 1975). Ten percent of the total amount of feces and $10 \%$ of the volume of produced urine were also collected daily and individually along with samples of the feed supplied and feed leftovers from the previous day. To avoid loss of nitrogenous compounds in the urine by evaporation, $10 \mathrm{~mL}$ of $10 \%$ hydrochloric acid solution was added to the container prior to collection.

The nitrogen balance was calculated using the following equations:

$$
\begin{aligned}
& \mathrm{N}_{\text {retained }}=\mathrm{N}_{\text {ingested }}-\left(\mathrm{N}_{\text {fecal }}+\mathrm{N}_{\text {urine }}\right) \\
& \mathrm{N}_{\text {absorbed }}=\mathrm{N}_{\text {ingested }}-\mathrm{N}_{\text {feces }}
\end{aligned}
$$

The feeding behavior analysis was conducted on the last day of the experiment by using a system of two trained raters, rotated in shifts every six hours and strategically positioned to avoid disturbing the animals, for a total of 288 observations per period. Data collections were performed in 5-minute periods over the 24-hour period of observation, and the evaluated behavioral variables included Feeding (F), Rumination (R) and Idleness (I). The barn was maintained with artificial lighting during the night period throughout the experimental period for animal adaptation.

The statistical analysis was performed using a completely randomized design (CRD) with four treatments and five replicates. The assumptions of normality of error and homogeneity of variance were met according to Cramer-von Mises and Brown and Forsythe's tests, respectively. The data were subjected to linear and quadratic regression analyses using the SISVAR software (FERREIRA, 2000). The statistical model used was as follows:

$$
\hat{\mathrm{Y}}_{\mathrm{ij}}=\mu+\mathrm{t}_{\mathrm{i}}+\mathrm{e}_{\mathrm{ij}} \text {, }
$$

Where:

$\hat{\mathrm{Y}}_{\mathrm{ij}}=$ the value observed in the experimental unit that received feed supplemented with tropical kudzu $\mathrm{i}$ on replicate $\mathrm{j} ; \mu=$ the overall mean; $\mathrm{t}_{\mathrm{i}}=$ the effect of supplementation with tropical kudzu $i$, with $\mathrm{i}=1,2,3$ and 4; ande $_{\mathrm{ij}}=$ the random error associated with each observation for treatment $i$ and replicate $\mathrm{j}$.

\section{Results and Discussion}

The effects of different concentrations of tropical kudzu on nutrient intake $\left(\mathrm{kg} \mathrm{day}^{-1}, \%\right.$ body weight (BW) and $\mathrm{g} /$ metabolic weight (MW)) from the evaluated diets are shown in Table 3. The intake of DM, OM, EE, CP, NDF, HEMI, TCHO, NFC and TDN expressed as $\mathrm{kg} /$ day showed no statistically significant differences $(p>0.05)$ between the studied concentrations, which indicates that dietary legume supplementation did not cause a limitation to animal feed intake and enabled voluntary intake, which are important results because they increase nutrient availability for metabolic processes and result in improved growth rates and reproductive performance (BARROS-RODRIGUEZ et al., 2013). Furthermore, the results showed that soybean meal might be replaced by tropical kudzu without compromising animal dietary intake, so it could be used as alternative for prime ingredients, which would reduce the feeding costs. 
Table 3. Nutrient intake $\left(\mathrm{kg} \mathrm{day}^{-1}, \%\right.$ of body weight - BW and unit of metabolic body weight $\left(\mathrm{g} / \mathrm{BW}^{0.75}\right)$ ) for ovine fed diets containing different concentrations of tropical kudzu.

\begin{tabular}{|c|c|c|c|c|c|}
\hline \multirow{2}{*}{ Item } & \multicolumn{4}{|c|}{ Concentrations of tropical kudzu in the roughage } & \multirow{2}{*}{ Regression } \\
\hline & $0 \%$ & $25 \%$ & $50 \%$ & $75 \%$ & \\
\hline & \multicolumn{4}{|c|}{ Nutrient intake $\left(\mathrm{kg} \mathrm{day}^{-1}\right)$} & \\
\hline DM & 1.02 & 1.22 & 0.99 & 1.23 & $\mathrm{Y}=1.12$ \\
\hline $\mathrm{OM}$ & 0.97 & 1.17 & 0.95 & 1.15 & $Y=1.06$ \\
\hline $\mathrm{EE}$ & 0.028 & 0.036 & 0.028 & 0.034 & $\mathrm{Y}=0.03$ \\
\hline $\mathrm{CP}$ & 0.15 & 0.18 & 0.14 & 0.17 & $Y=0.16$ \\
\hline NDF & 0.41 & 0.48 & 0.38 & 0.45 & $\mathrm{Y}=0.43$ \\
\hline HEMI & 0.17 & 0.19 & 0.14 & 0.16 & $\mathrm{Y}=0.17$ \\
\hline $\mathrm{TC}$ & 0.79 & 0.95 & 0.78 & 0.95 & $\mathrm{Y}=0.87$ \\
\hline NFC & 0.38 & 0.47 & 0.40 & 0.50 & $Y=0.44$ \\
\hline \multirow[t]{2}{*}{ TDN } & 0.74 & 0.88 & 0.75 & 0.91 & $\mathrm{Y}=0.82$ \\
\hline & \multicolumn{4}{|c|}{ Nutrient intake (\% of BW) } & \\
\hline $\mathrm{DM}$ & 3.16 & 3.82 & 2.98 & 3.92 & $\mathrm{Y}=3.47$ \\
\hline $\mathrm{OM}$ & 3.02 & 3.66 & 2.86 & 3.65 & $\mathrm{Y}=3.30$ \\
\hline $\mathrm{EE}$ & 0.088 & 0.11 & 0.09 & 0.1 & $Y=0.10$ \\
\hline $\mathrm{CP}$ & 0.47 & 0.56 & 0.43 & 0.54 & $\mathrm{Y}=0.50$ \\
\hline NDF & 1.28 & 1.51 & 1.15 & 1.42 & $\mathrm{Y}=1.34$ \\
\hline HEMI & 0.53 & 0.6 & 0.43 & 0.52 & $\mathrm{Y}=0.52$ \\
\hline $\mathrm{TC}$ & 1.18 & 1.47 & 1.2 & 1.57 & $\mathrm{Y}=1.36$ \\
\hline NFC & 2.46 & 2.98 & 2.35 & 3.00 & $\mathrm{Y}=2.70$ \\
\hline \multirow[t]{2}{*}{ TDN } & 2.3 & 2.76 & 2.26 & 2.88 & $\mathrm{Y}=2.55$ \\
\hline & \multicolumn{4}{|c|}{ Nutrient intake (unit of metabolic body weight $\left(\mathrm{g} / \mathrm{BW}^{0.75}\right)$ ) } & \\
\hline $\mathrm{DM}$ & 7.52 & 9.08 & 7.15 & 9.25 & $\mathrm{Y}=8.25$ \\
\hline $\mathrm{OM}$ & 7.2 & 8.68 & 6.85 & 8.62 & $\mathrm{Y}=7.84$ \\
\hline $\mathrm{EE}$ & 0.21 & 0.26 & 0.2 & 0.26 & $\mathrm{Y}=0.23$ \\
\hline $\mathrm{CP}$ & 1.13 & 1.33 & 1.03 & 1.28 & $\mathrm{Y}=1.19$ \\
\hline NDF & 3.05 & 3.59 & 2.75 & 3.36 & $\mathrm{Y}=3.19$ \\
\hline HEMI & 1.25 & 1.42 & 1.03 & 1.22 & $\mathrm{Y}=1.23$ \\
\hline $\mathrm{TC}$ & 2.81 & 3.5 & 2.87 & 3.72 & $\mathrm{Y}=3.23$ \\
\hline NFC & 5.86 & 7.09 & 5.62 & 7.08 & $\mathrm{Y}=6.41$ \\
\hline TDN & 5.48 & 6.55 & 5.42 & 6.8 & $\mathrm{Y}=6.06$ \\
\hline
\end{tabular}

$\mathrm{DM}=$ dry matter; $\mathrm{OM}=$ organic matter; $\mathrm{MM}=$ mineral matter $($ ash $) ; \mathrm{CP}=$ crude protein; $\mathrm{EE}=$ ether extract; $\mathrm{NDF}=$ neutral detergent fiber; HEMI $=$ hemicellulose; $\mathrm{TC}=$ total carbohydrates; $\mathrm{NFC}=$ non-fiber carbohydrates.

The DM and OM intake in \% body weight (BW) and metabolic weight showed no statistically significant difference $(p>0.05)$ between the concentrations of evaluated tropical kudzu. This result met the nutritional requirements of the NRC tables (2007), suggesting that meat-producing sheep ingest between 3.01 and $4.25 \%$ BW of DM/ day. In evaluations of dietary supplementation with different concentrations (25, 50, 75 and $100 \%$ on DM basis) of tropical kudzu to replace Brachiaria humidicola in sheep diets, Monteiro et al. (2012) found that the DM intake in \% BW increased, with maximum values of $1.23 \% \mathrm{BW}$ when the animals were fed tropical kudzu exclusively.

No statistically significant differences $(p>0.05)$ were found in EE intake based on body weight and metabolic weight in the treatments studied, which may be explained by the similarity between the EE levels of Elephant grass (3.22) and tropical kudzu 
(2.01) and the similar EE concentrations maintained in the diets despite replacing one ingredient with the other.

The crude protein intake based on body weight and metabolic weight showed no statistically significant difference $(p>0.05)$ between treatments. This result may be explained by the formulation of the diets, which are isoproteic, combined with the dry matter intake, which also showed no statistically significant difference between treatments $(p>0.05)$. These results were similar to those found by Ladeira et al. (2002), who recorded a value of 0.57 of CP intake based on body weight when studying sheep diets supplemented with Arachispintoi hay. The intake of all the animals met the values predicted by the nutritional requirements tables of the NRC (2007), which recommend that sheep with $30 \mathrm{~kg}$ BW gain from 200 to $400 \mathrm{~g} /$ day and ingest from 129 to $207 \mathrm{~g} \mathrm{CP} /$ day. Therefore, protein must be present at appropriate concentrations in the diet because it promotes an increase in weight gain of farm animals by providing nitrogen substrates that are suitable for the growth and multiplication of ruminal microorganisms (FICK et al., 1973).

No statistically significant differences $(p>0.05)$ were found between the diets based on the intake (\% live weight (LW) and g/MW) of NDF and hemicellulose, despite the increased lignin levels observed for the treatments (Table 2). The components representing the fiber portion of feed (NDF) are among the physical factors affecting feed intake, and the increase in NDF intake may have caused a decrease in DM intake because it leads to a smaller rate of ruminal passage and rumen fill (MERTENS, 1992). Thus, the similarities in NDF intake between diets in the present study were most likely induced by the similarities in DM intakes. According to Mertens (1994), an NDF intake of up to $1.8 \% \mathrm{BW}$ is the maximum value at which the diet may be ingested without compromising the intake as a result of the energy density of the diet.

The NFC and TCHO intakes based on $\mathrm{kg} /$ day, body weight and metabolic weight showed no statistically significant differences $(\mathrm{p}>0.05)$ between the evaluated diets because no changes were found for most of the factors that compose the dietary total carbohydrates and fiber components, including $\mathrm{CP}, \mathrm{EE}, \mathrm{MM}$ and NDF.

No dietary effect $(\mathrm{p}>0.05)$ occurred for the variable TDN intake ( $\mathrm{kg} /$ day, $\% \mathrm{BW}$ and $\mathrm{g} / \mathrm{MW})$, which showed that sheep fed diets containing all of the concentrations of tropical kudzu ingested the same levels of total digestible nutrients as the animals that ingested feed without tropical kudzu. The lack of an effect was indicated by the similar intake of TDN components CP, EE, NDF and NFC.

The dietary concentrations of tropical kudzu had no effect on the digestibility of any of the studied factors $(\mathrm{p}>0.05)$, including digestible dry matter (DDM), digestible organic matter (DOM), digestible ether extract (DEE), digestible crude protein (DCP), digestible neutral detergent fiber (DNDF), digestible hemicellulose (DHEMI), digestible non-fiber carbohydrates (DNFC) and TDN (Table 4). These results may be explained by the lack of an effect observed based on the nutrient intake with different diets because digestibility is directly affected by the voluntary intake of animals. Longo et al. (2008) also observed a lack of fit of the regression equation of DM and CP digestibility when assessing dietary supplementation with leucaena as a protein source in sheep. 
Table 4. Apparent digestibility of nutrients obtained in ovine fed diets containing different concentrations of tropical kudzu.

\begin{tabular}{lccccc}
\hline \multirow{2}{*}{ Item } & \multicolumn{3}{c}{ Concentrations of tropical kudzu in the roughage } & \multirow{2}{*}{ Regression } \\
\cline { 2 - 5 } & $0 \%$ & $25 \%$ & $50 \%$ & $75 \%$ & \\
\hline DMD & 71.25 & 70.2 & 72.35 & 72.72 & $\mathrm{Y}=71.63$ \\
OMD & 72.81 & 73.25 & 76.61 & 74.74 & $\mathrm{Y}=74.35$ \\
EED & 84.46 & 86.48 & 80.6 & 84.6 & $\mathrm{Y}=84.04$ \\
CPD & 75.00 & 72.27 & 73.11 & 72.18 & $\mathrm{Y}=73.14$ \\
NDFD & 51.79 & 50.55 & 56.17 & 50.33 & $\mathrm{Y}=52.21$ \\
HEMID & 21.32 & 20.23 & 18.74 & 15.39 & $\mathrm{Y}=18.92$ \\
NFCD & 94.53 & 96.03 & 97.07 & 96.98 & $\mathrm{Y}=96.15$ \\
\% TDN & 72.04 & 72.46 & 75.69 & 74.79 & $\mathrm{Y}=73.74$ \\
\hline
\end{tabular}

$\mathrm{DM}=$ dry matter $\mathrm{OM}=$ organic matter; $\mathrm{EE}=$ ether extract; $\mathrm{CP}=$ crude protein; $\mathrm{NDF}=$ neutral detergent fiber; $\mathrm{HEMI}=$ hemicellulose; $\mathrm{NFC}=$ non-fiber carbohydrates; $\mathrm{TC}=$ total carbohydrates; TDN $=$ total digestible nutrients.

Legumes are known to have significant levels of tannins (NOZELLA, 2001; ARAUJO FILHO; CARVALHO, 1998), which can cause decreased palatability and may form complexes with proteins that would decrease the $\mathrm{N}$ availability to ruminal microorganisms and impair the apparent digestibility of nutrients (McSWEENEY et al., 2001). Longo et al. (2008) also observed that delayed fiber digestion caused a smaller digestibility of NDF in diets supplemented with leucaena because of the presence of tannins. When assessing the dietary replacement of Brachiaria humidicolaby tropical kudzu in sheep, Monteiro et al. (2012) found that the tannin levels in those diets increased linearly with legume supplementation. Those tannins had no effect on the NDF digestibility, despite the evidence reported in the literature on tannin effects on the digestibility of fiber components and the presence of those phenolic compounds in the legume studied.

The analysis of NFC digestibility showed no statistically significant difference $(p>0.05)$ between the diets studied, despite the findings by Schofield et al. (2001), who claimed that tannins are anti-nutritional factors that primarily affect NFC digestibility by decreasing the intake as a result of decreased palatability. The results were similar to those reported by Ladeira et al. (2002), who recorded a value of $93.3 \%$ when studying dietary supplementation with Arachis pintoi hay in sheep. The values found in the present study corroborate those reported in the literature, wherein non-fibrous carbohydrates in food show fast, complete and constant nutritional availability from 98 to $100 \%$ (VAN SOEST, 1994).

The TDN levels showed no statistically significant differences ( $>00.05)$ upon dietary supplementation with tropical kudzu, which is a similar result to that of Goyanna (2009), who recorded a value of $70.81 \%$ total digestible nutrients when studying the apparent digestibility of 'sabiá' hay. This result is explained by the lack of differences observed in the nutrients that compose the TDN portion, which are CP, EE, NDF and NFC.

Table 5 presents the data regarding nitrogen balance, which shows no statistically significant differences for the analyzed variables $(p>0.05)$. The nitrogen excreted in urine, which is measured using the urea concentration, is positively correlated with the plasma nitrogen concentrations and nitrogen intake and is an indicator of the efficacy of ruminal nitrogen use according to Van Soest (1994). Moreover, one of the factors promoting an increase 
in the levels of fecal excretion of nitrogen is the presence of condensed tannins in the diet (MOULD; decrease in apparent digestibility resulting from the ROBBINS, 1981).

Table 5. Values of nitrogen balance for each treatment containing different concentrations of tropical kudzu.

\begin{tabular}{lccccc}
\hline \multirow{2}{*}{\multicolumn{1}{c}{ Parameters }} & \multicolumn{4}{c}{ Concentrations of tropical kudzu in the roughage } & \multirow{2}{*}{ Regression } \\
\cline { 2 - 5 } & $0 \%$ & $25 \%$ & $50 \%$ & $75 \%$ & \\
\hline Nitrogen intake, g/day & 24.34 & 28.61 & 22.74 & 27.35 & $\mathrm{Y}=25.76$ \\
Fecal nitrogen, g/day & 6.1 & 8.52 & 6.14 & 7.59 & $\mathrm{Y}=7.09$ \\
Nitrogen absorbed, g/day & 18.24 & 20.09 & 16.6 & 19.76 & $\mathrm{Y}=18.67$ \\
Urinary Nitrogen, g/day & 5.17 & 4.41 & 3.67 & 3.3 & $\mathrm{Y}=4.14$ \\
Nitrogen retained g/day & 13.07 & 15.68 & 12.93 & 16.46 & $\mathrm{Y}=14.54$ \\
\hline
\end{tabular}

Therefore, the positive nitrogen balance observed in all of the treatments indicated that no loss of protein or nitrogen compounds occurred during the experimental period, showing that the dietary protein fraction was efficiently used by the animals (COSTA et al., 2008). Moreover, according to Lavezzo et al. (1996), the nitrogen fraction is used efficiently by ruminants when a low excretion of urinary $\mathrm{N}$ occurs along with adequate nitrogen intake and absorption. Thus, the positive balance indicates that protein retention occurred in the animal body in all of the diets.

No statistically significant differences $(p>0.05)$ regarding feeding behavior (Table 6) were observed in the feeding, rumination and idle times of sheep fed different diets. These values may be explained by the lack of statistically significant differences in sheep dry matter intake (DMI; $\mathrm{g} / \mathrm{kg}, \% \mathrm{BW}$ and $\mathrm{g} / \mathrm{MW}$ ) between the dietary concentrations of tropical kudzu in this study. The variable dry matter intake has a significant effect on feeding behavior because the animal ingests food until reaching maximum intake capacity, which characterizes rumen fill according to Mertens (1994). Furthermore, the similar digestibility observed in all of the treatments indicates that no differences occurred in the feeding or rumination times for diets with greater concentrations of tropical kudzu.

Table 6. Average spending time (h/day) with eating, ruminating and idle in ovine fed diets containing different concentrations of tropical kudzu.

\begin{tabular}{lccccc}
\hline \multirow{2}{*}{\multicolumn{1}{c}{ Item }} & \multicolumn{4}{c}{ Concentrations of tropical kudzu in the roughage } & \multirow{2}{*}{ Regression } \\
\cline { 2 - 5 } & $0 \%$ & $25 \%$ & $50 \%$ & $75 \%$ & \\
\hline Feeding time (h/day) & 4.35 & 4.43 & 4.45 & 4.12 & $\mathrm{Y}=4.34$ \\
Rumination time (h/day) & 9.02 & 8.65 & 9.02 & 9.17 & $\mathrm{Y}=8.97$ \\
Idle time (h/day) & 10.62 & 10.88 & 10.45 & 10.62 & $\mathrm{Y}=10.64$ \\
\hline
\end{tabular}

The results found in the present study show that the dietary replacement of soybean meal by tropical kudzu may be conducted in sheep without decreasing the dietary nutritional quality because the intake, digestibility, feeding behavior and nitrogen balance of diets supplemented with 
tropical kudzu showed no statistically significant differences from the treatment without its use. Furthermore, the use of tropical kudzu reduces the costs of sheep feeding because the price of soybean meal (50 kg) is US\$25.98 (CONAB, 2014), which greatly increases the feed costs. Although the amount of corn increases with supplementation by tropical kudzu, this ingredient is priced at nearly half the value of soybean meal at US\$13.67 (60 kg) (CONAB, 2014). Thus, a satisfactory economic result is obtained when using corn. Therefore, tropical kudzu may be used as a protein supplement because this legume is a nutritional source favorable to animals and an economical alternative.

Sheep dietary supplementation with tropical kudzu has no effect on the intake or digestibility of dietary components, nitrogen balance values (ingested, fecal, absorbed, urinary and retained nitrogen), feeding, rumination and idle times in $\mathrm{h} /$ day (digestive behavior). Therefore, tropical kudzu is a good option for the replacement of prime foods (in this case, soybean meal) in animal diets, which makes the production of sheep more sustainable.

\section{Acknowledgments}

We would like to thank the Study Group on Ruminants and Forage Production of the Amazon (Grupo de Estudo em Ruminantes e Forragicultura da Amazônia, GERFAM), Center for Research on Goats and Sheep of Pará (Centro de Pesquisa em Caprinos e Ovinos do Pará, CPCOP) and Coordination for the Improvement of Higher Education Personnel (Coordenação de Aperfeiçoamento de Pessoal de Nível Superior, CAPES) for granting the scholarship that provided the funding required to conduct this master's dissertation, and we would also like to thank the Federal Rural University of the Amazon (Universidade Federal Rural da Amazônia, UFRA) for funding the publication of this study.

\section{References}

ALMEIDA, J. C. C.; ROCHA, N. S.; NEPOMUCENO, D. D.; ARAÚJO, R. P.; SILVA, T. O.; MORENZ, M. J. F.; ABREU, J. B. R.; CARVALHO, C. A. B.; MACEDO, R. O. Composição mineral de leguminosas forrageiras cultivadas sob diferentes níveis de sombreamento. Semina: Ciências Agrárias, Londrina, v. 36, n. 1, p. $367-$ $375,2015$.

ALVES, T. C.; FRANZOLIN, R.; RODRIGUES, P. H. M.; ALVES, A. C. Efeitos de dietas com níveis crescentes de milho no metabolismo ruminal de energia e proteína em bubalinos. Revista Brasileira de Zootecnia, Viçosa, MG, v. 38, n. 10, p. 2001-2006, 2009.

ARAUJO FILHO, J. A.; CARVALHO, F. C. Fenologia e valor nutritivo de espécies lenhosas caducifólias da Caatinga. Sobral: Embrapa Centro Nacional de Pesquisa de Caprinos/CNPC, 1998. 5 p. (Embrapa Centro Nacional de Pesquisa de Caprinos. Comunicado técnico, 39).

ASSOCIATION OF OFFICIAL ANALYTICAL CHEMISTS - AOAC. Official methods of analysis. $15^{\text {th }}$ ed. Arlington: Pharmabooks. 1990. 1117 p.

BARCELLOS, A. O.; RAMOS, A. K. B.; VILELA, L.; MARTHA JUNIOR, G. B. Sustentabilidade da produção animal baseada em pastagens consorciadas e no emprego de leguminosas exclusivas, na forma de banco de proteína, nos trópicos brasileiros. Revista Brasileira de Zootecnia, Viçosa, MG, v. 37, p. 51-67, 2008. Suplemento.

BARROS-RODRIGUEZ, M.; SOLORIO-SÁNCHEZ, J.; SANDOVAL-CASTRO, C.; KLIEVE, A. V.; BRICEÑO-POOT, E.; RAMÍREZ-AVILÉS, L.; ROJASHERRERA, R. Effects of two intake levels of Leucaena leucocephala on rumen function of sheep. Tropical Grasslands, Cali, v. 1, n. 1, p. 55-57, 2013.

COMPANHIA NACIONAL DE ABASTECIMENTO CONAB. Preços agrícolas, da sociobio e da pesca - milho e farelo de soja. Brasília: [s.n.], 2014. Disponível em: $<$ http://sisdep.conab.gov.br/precosiagroweb/>. Acesso em: 2 fev. 2014.

CORLEY, R. N.; WOLDEGHEBRIEL, A.; MURPHY, M. R. Evaluation of the nutritive value of kudzu (Pueraria Lobata) as a feed for ruminants. Animal Feed Science and Technology, Amsterdam, v. 68, n. 1-2, p. 183-188, 1997.

COSTA, H. H. A.; FREIRE, A. P. A.; BARBOSA, J. S. R.; MESQUITA JÚNIOR, E. M. de; SILVA, V. L.; PRIMO, T. S.; ARAÚJO, A. R.; RIBEIRO, T. da P.; ROGÉRIO, M. C. P. Concentrações de nitrogênio amoniacal em ovinos alimentados com dietas contendo silagem de pasto nativo do nordeste brasileiro e co-produto de urucum, 
formuladas conforme o NRC (1985) e o NRC (2007). In: CONGRESSO BRASILEIRO DE NUTRIÇÃO ANIMAL, 1., 2008, Fortaleza. Biotecnologia aplicada na produção de rações. Anais... Fortaleza: SEBRAE-CE, Seção Manejo e Nutrição de Ruminantes, 2008. CDROM.

FERREIRA, D. F. Análises estatísticas por meio do SISVAR para Windows versão 5.3. In: REUNIÃO ANUAL DA REGIÃO BRASILEIRA DA SOCIEDADE INTERNACIONAL DE BIOMETRIA, 45., 2000, São Carlos. Resumos... São Carlos: UFSCar, 2000. 235 p.

FICK, K. R.; AMMERMAN, C. B.; McGOWAN, C. H.; LOGGINS, P. E.; CORNELL, J. A. Influence of supplemental energy and biuret nitrogen on the utilization of low quality roughage by sheep. Journal of Animal Science, Champaign, v. 36, n. 1, p. 137-143, 1973.

GOYANNA, G. J. F. Caracterização nutricional dos fenos de sabiá (Mimosa caeslpiniifolia BENTH) $e$ mororó (Bauhinia cheilantha (BONG) STEUD) em caprinos. 2009. Dissertação (Mestrado em Zootecnia) Universidade Federal Rural de Pernambuco, Recife.

INSTITUTO BRASILEIRO DE GEOGRAFIA E ESTATÍSTICA - IBGE. Produção da pecuária mundial. Rio de Janeiro: Ministério do Planejamento, Orçamento e Gestão, 2013. Disponível em: <ftp://ftp. ibge.gov.br/Producao_Pecuaria/Producao_da_Pecuaria_ Municipal/2013/ppm2013.pdf>. Acesso em: 18 jan. 2013.

LADEIRA, M. M.; RODRIGUEZ, N. M.; BORGES, I.; GOLÇALVES, L. C.; SALIBA, E. O. S.; BRITO, S. C.; SA, L. A. P. Avaliação do feno de Arachis pintoi utilizando o ensaio de digestibilidade in Vivo. Revista Brasileira de Zootecnia, Viçosa, MG, v. 31, n. 6, p. 23502356, 2002.

LAVEZZO, O. E. N. M.; LAVEZZO, W.; BURINI, R. C. Efeitos nutricionais da substituição parcial do farelo de soja por uréia, em dietas de ovinos: comparação da digestibilidade aparente e balanço de nitrogênio com a cinética do metabolismo da $15 \mathrm{~N}$-glicina. Revista Brasileira de Zootecnia, Viçosa, MG, v. 25, n. 2, p. 282297, 1996.

LONGO, C.; NOZELLA, E. F.; CABRAL FILHO, S. L. S.; LAVORENTI, N.; VITTI, D. M. S. S.; ABDALLA, A. L. Voluntary intake, apparent digestibility and nitrogen balance by sheep supplemented with Leucaena leucocephala.Livestock Research for RuralDevelopment, Cali, v. 20, n. 11, art. 184, 2008. Disponível em: < http:// www.lrrd.org/lrrd20/11/long20184.htm>. Acesso em: 03 maio 2014.
MERTENS, D. R. Analysis of fiber in feeds and its use in feed evaluation and ration formulation. In: SIMPÓSIO INTERNACIONAL DE RUMINANTES, 1992, Lavras. Anais... Lavras: SBZ, 1992. p. 1-33.

MERTENS, D. R. Regulation of forage intake. In: FAHEY JUNIOR, G. C.; COLLINS, M.; MERTENS, D. R.; MOSER, L. E. (Ed.). Forage quality, evaluation, and utilization. Madison: American Society of Agronomy, Crop Science Society of America, and Soil Science Society of America, 1994. p. 450-493.

McSWEENEY, C. S.; PALMER, B.; McNEILL, D. M.; KRAUSE, D. O microbial interactions with tannins: nutritional consequences for ruminants. Animal Feed Science and Technology, Amsterdam, v. 91, n. 1-2, p. 8393, 2001.

MILLEN, D. D.; PACHECO, R. D. L.; ARRIGONI, M. D. B.; GALYEAN, M. L.; VASCONCELOS, J. T. A snapshot of management practices and nutritional recommendations used by feedlot nutritionists in Brazil. Journal of Animal Science, Champaign, v. 87, n. 7, p. 3427-3439, 2009.

MIRANDA, C. H. B.; VIEIRA, A.; CADISCH, G. Determinação da fixação biológica do amendoim forrageiro (Arachis spp.) por intermédio da abundância natural de 15N. Revista Brasileira de Zootecnia, Viçosa, MG, v. 32, p. 1859-1865, 2003. Suplemento 2.

MONTEIRO, E. M. M.; LOURENÇO JÚNIOR, J. B.; GARCIA, A. R.; NAHÚM, B. S.; SANTOS, N. F. A.; FERREIRA, G. D. G. Consumo e digestibilidade aparente da matéria seca, matéria orgânica e proteína bruta da Pueraria phaseoloides (Roxb.) Benth por ovinos. Semina: Ciências Agrárias, Londrina, v. 33, n. 1, p. 417-426, 2012.

MOULD, E. D.; ROBBINS, C. T. Nitrogen metabolism in elk. Journal Wildl. Management, Malden, v. 45, n. 2, p. 323-334, 1981.

NATIONAL RESEARCH COUNCIL - NRC. Nutrient requirement of small ruminants: sheep, goats, cervids and new camelids. Washington: National Academy Press, 2007. 384 p.

NOZELLA, E. F. Determinação de taninos em plantas com potencial forrageiro para ruminantes. 2001. Dissertação (Mestrado em Ciências) - Centro de Energia Nuclear na Agricultura, Universidade de São Paulo, Piracicaba.

ROTZ, C. A. Field curing of forages. In: MOORE, K .J.; KRAL, D. M.; VINEY, M. K. (Ed.). Post-harvest physiology and preservation of forages. Madison: American Society of Agronomy, 1995. p. 39-66, 
SCHNEIDER, B. H.; FLATT, W. P. The evaluation of feeds through digestibility experiments. Athens: University of Georgia Press, 1975. 369 p.

SCHOFIELD, P.; MBUGUA, D. M.; PELL, A. N. Analysis of condensed tannins: a review. Animal Feed Science and Technology, Amsterdam, v. 91, n. 1-2, p. 21-40, 2001.

SILVA, M. S.; TREMBLAY, G. F.; BÉLANGER, G.; LAJEUNESSE, J.; PAPADOPOULOS, Y. A.; FILLMORE, S. A. E.; JOBIM, C. C. Forage energy to protein ratio of several legume-grass complex mixtures. Animal Feed Science and Technology, Amsterdam, v. 188, n. 1, p. 17-27, 2014.

SNIFFEN, C. J.; O’CONNOR, J. D.; VAN SOEST, P. S. A net carbohydrate and protein availability. Journal of Animal Science, Champaign, v. 70, n. 11, p. 3562-3577, 1992.

TERRILL, T. H. S.; GELAYE, S.; MAHOTIERE, E. A.; AMOAH, S.; MILLER, W. R. Effect of cutting date and frequency on yield and quality of kudzu in the Southern United States. Grass Forage Science, Malden, v. 58, n. 2, p. 178-183, 2003.

VALENTIM, J. F.; CARNEIRO, J. C. Quebra da dormência e plantio de puerária em sistemas de produção agropecuários e agroflorestais. Rio Branco: Embrapa Acre/ASB, 1998. 3 p. (Embrapa Acre. Instruções Técnicas, 17).
VAN HIEP, N.; WIKTORSSON, H.; VAN MAN, N. The effect of molasses on the quality of Kudzu silage and evaluation of feed intake and digestibility of diets supplemented with Kudzu silage or Kudzu hay by heifers. Livestock Research for Rural Development, Cali, v. 20, 2008. Supplement. Available at: <http:// www.lrrd.org/lrrd20/supplement/hiep2.htm>. Accessed at: 05 fev. 2014.

VAN SOEST, P. J. Nutritional ecology of the ruminant. $2^{\text {th }}$ ed. Ithaca: Cornell University Press, 1994. 476 p.

VAN SOEST, P. J.; WINE, R. H. Use of detergents in the analysis of fibrous feeds. IV determination of plant cellwall constituents. Journal of the Official Agricultural Chemist, Toronto, v. 50, n. 1, p. 50-55, 1967.

VASTA, V.; NUDDA, A.; CANNAS, A.; LANZA, M.; PRIOLO, A. Alternative feed resources and their effects on the quality of meat and milk from small ruminants. Animal Feed Science and Technology, Amsterdam, v. 147, n. 1-3, p. 223-246, 2008.

WILKINS, R. J.; JONES, R. Alternative home-grown protein sources for ruminants in the United Kingdom. Animal Feed Science and Technology, Amsterdam, v. 85, n. 1-2, p. 23-32, 2000. 
